\title{
PENGARUH LEVERAGE, PERTUMBUHAN \\ PENJUALAN DAN UKURAN PERUSAHAAN \\ TERHADAP PROFITABILITAS PERUSAHAAN \\ (Studi pada Perusahaan Plastik dan Kemasan yang \\ Terdaftar pada Bursa Efek Indonesia \\ pada Tahun 2012-2016)
}

\author{
Ahmad Wandri, Aminar Sutra Dewi \\ Sekolah Tinggi Ilmu Ekonomi KBP \\ wandrilaw@yahoo.com
}

\begin{abstract}
Plastic and packaging companies suffered losses due to imported raw materials from abroad. The purpose of this study is to determine the effect of leverage, sales growth, and company size on profitability in plastic and packaging companies listed on the Indonesia Stock Exchange from 2012 until 2016. The results explain that the higher the leverage will decrease the profitability of the company, the higher the sales growth the higher the profitability, and the higher the size of the company will decrease the profitability of the company. Based on the partial t test it can be concluded that leverage has a negative and significant effect on profitability because the probability value is $0.0003<0,05$. Based on the partial $t$ test can be concluded that sales growth does not affect the profitability because the probability value of $0.9221>0.05$. Based on the partial $t$ test can be concluded that firm size does not affect the profitability because the probability value of $0.3529>0.05$. The ability of independen to influence dependen is $21,94 \%$ while the rest equal to 78,06\% influenced by other variable beside of variable which is researched.
\end{abstract}

Keyword: Leverage, Sales Growth, Company Size and Profitability

PENDAHULUAN

Profitabilitas adalah kemampuan sebuah perusahaan dalam memperoleh laba yang hubungannya dengan penjualan, total aktiva, maupun modal sendiri (Sartono, 2010). Jumlah laba bersih sering dibandingkan dengan ukuran kegiatan atau kondisi keuangan lainnya seperti penjualan, aktiva, ekuitas pemegang saham. Besarnya laba juga digunakan untuk menilai kinerja perusahaan. Bagi pemimpin perusahaan manufaktur, profitabilitas dapat digunakan sebagai tolak ukur untuk mengetahui berhasil atau tidaknya perusahaan yang dipimpinnya sedangkan bagi penanam modal dapat digunakan sebagai tolak ukur prospek modal yang ditanamkan dalam perusahaan tersebut. Suatu perusahaan dikatakan baik apabila perusahaan tersebut dapat beroperasi secara stabil dalam jangka waktu yang panjang sehingga perusahaan tidak akan mengalami kesulitan mengembalikan hutang-hutangnya baik hutang jangka pendek maupun hutang jangka panjang.

Leverage adalah salah satu faktor penting untuk mempengaruhi profitablitas karena leverage bisa digunakan perusahaan untuk meningkatkan modal perusahaan dalam rangka menigkatkan keuntungan (Singapurwoko, 2011). Pembiayaan dengan utang atau Leverage keuangan menurut Brigham dan 
Houston (2001) memiliki tiga implikasi penting, yaitu : pertama, memperoleh dana melalui hutang membuat pemegang saham dapat mempertahankan pengendalian atas perusahaan dengan investasi yang terbatas. Kedua, kreditur melihat ekuitas atau dana yang disetor pemilik untuk memberikan margin safety, sehingga jika pemegang saham hanya memberikan sebagian kecil dari total pembiayaan, maka risiko perusahaan sebagian besar ada pada kreditur. Ketiga, jika perusahaan memperoleh pengembalian yang lebih besar atas investasi yang dibiayai dengan dana pinjaman dibandingkan pembayaran bunga, maka pengembalian atas modal pemilik akan lebih besar.

Pertumbuhan penjualan adalah kenaikan jumlah penjualan dari tahun ke tahun atau dari waktu ke waktu (Kennedy dkk, 2013). Penjualan merupakan kriteria penting untuk menilai profitabilitas perusahaan dan merupakan indicator utama atas aktivitas perusahaan (Andrayani, 2013). Pertumbuhan penjualan memiliki pengaruh yang strategis bagi perusahaan karena pertumbuhan penjualan ditandai dengan peningkatan market share yang akan berdampak pada penigkatan penjualan dari perusahaan, sehingga akan menigkatkan profitabilitas dari perusahaan (pagano dan Schivardi, 2003).

Perusahaan dangan ukuran yang lebih besar memiliki akses yang lebih besar untuk mendapat sumber pendanaan dari berbagai sumber, sehingga untuk memperoleh pinjaman dari kreditur akan lebih mudahkarena perusahaan dengan ukuran besar memiliki profitabilitas lebih besar untuk memenangkan persaingan atau bertahan dalam industry. Pada sisi lain, perusahaan dengan skala kecil lebih fleksibel dalam menghadapi ketidakpastian, karena perusahaan kecil lebih cepat bereaksi terhadap perubahan mendadak. Oleh karena itu, memungkinkan perubahan besar tingkat leverage-nya akan lebih besar dari perusahaan kecil.

Leverage adalah penggunaan assets dan sumber dana oleh perusahaan yang memiliki biaya tetap (beban tetap) dengan maksud agar meningkatkan keuntungan potensial pemegang saham. Dari pengertian tersebut dapat diketahui bahwa leverage adalah penggunaan asset dan sumber dana yang memiliki biaya atau beban tetap yang berasal dari pinjaman dengan maksud agar meningkatkan keuntungan potensial pemegang saham. Atau, leverage merupakan jumlah utang yang digunakan untuk membiayai/membeli aset-aset perusahaan.

Halim (2005:42) mengemukakan pengaruh leverage terhadap profitabilitas sebagai berikut : Debt-to-total-asset rasio merupakan rasio yang menggambarkan tingkat sumber dana utang dalam stuktur modal perusahaan yang digunakan untuk membiayai aset perusahaan. Penggunaan utang yang relatif tinggi akan menimbulkan biaya tetap berupa beban bunga dan angsuran pokok pinjaman yang harus dibayar, yang semakin besar biaya tetap dapat berakibat menurutnya laba perusahaan. Perusahaan yang mendanai assetnya dengan hutang, profitabilitasnya akan menurun karena perusahaan harus memenuhi beban yang harus dibayar dari penggunaan hutang tersebut (bunga). Selain itu, perusahaan memiliki risiko keuangan yang tinggi karena perusahaan terlalu banyak melakukan pendanaan aktiva dari hutang. Seperti adanya risiko gagal bayar, maka biaya yang harus dikeluarkan oleh perusahaan untuk mengatasi masalah ini semakin besar. Maka Hipotesis pertama, diduga Leverage berpengaruh negatif dan tidak signifikan terhadap Profitabilitas.

Pertumbuhan penjualan memiliki pengaruh terhadap profitabilitas perusahaan sebagaimana pernyataan Brigham dan Houston yang telah 
dialihbahasakan oleh Ali Akbar Yulianto (2010:168) menyatakan bahwa penjualan harus dapat menutupi biaya sehingga dapat meningkatkan keuntungan. Dari pernyataan tersebut dapat disimpulkan bahwa, pertumbuhan penjualan dapat meningkatkan keuntungan perusahaan. Selain itu, jika perusahaan dapat mengestimasi tingkat permintaan penjualan di masa mendatang dan mengalokasikan pembayaran utangnya, maka perusahaan akan mendapatkan laba yang maksimal.

Elfianto Nugroho (2011), melakukan penelitian dengan judul Analisis Pengaruh Likuiditas, Pertumbuhan Penjualan, Perputaran Modal Kerja, Ukuran Perusahaan, dan Leverage terhadap profitabilitas pada perusahaan manufaktur yang terdaftar di BEI pada tahun 2005-2009 memberikan kesimpulan bahwa variabel likuiditas berpengaruh positif tidak signifikan terhadap profitabilitas, variabel pertumbuhan penjualan berpengaruh negatif dan tidak signifikan, variabel perputaran modal kerja dan ukuran perusahaan berpengaruh posotif signifikan terhadap profitabilitas, serta variabel leverage berpengaruh negatif signifikan terhadap profitabilitas. Walaupun mengacu pada penelitian penelitian tersebut, terdapat perbedaan perusahaan yang digunakan untuk penelitian dan tahun penelitian. Maka Hipotesis kedua, diduga Pertumbuhan pemjualan berpengaruh negative dan signifikan terhadap Profitabilitas.

Dengan adanya sumber daya yang besar, maka perusahaan dapat melakukan investasi baik untuk aktiva lancar maupun aktiva tetap dan juga memenuhi permintaan produk. Hal ini akan semakin memperluas pangsa pasar. Dengan adanya penjualan yang semakin meningkat, perusahaan dapat menutup biaya yang keluar pada saat proses produksi. Dengan begitu, laba perusahaan akan meningkat. Abdul Raheman dan Mohamed Nasr (2007) meneliti tentang manajemen modal kerja dan profitabilitas pada perusahaan Pakistan. Dalam penelitian ini menggunakan sampel dari 94 perusahaan Pakistan yang terdaftar di Bursa Efek Karachi selama 6 tahun pada periode 1999-2004. Penelitian ini menggunakan analisis regresi dan korelasi. Rasio hutang, ukuran perusahaan (diukur dari segi logaritma alami penjualan) dan aset keuangan terhadap total aktiva telah digunakan sebagai variabel kontrol. Hasil penelitian menunjukkan bahwa ada hubungan negatif yang kuat antara variabel manajemen modal kerja dan profitabilitas perusahaan. Maka hipotesis ketiga, diduga Ukuran Perusahaan berpengaruh positif terhadap profitabilitas

\section{METODE PENELITIAN}

Jenis dan pendekatan yang digunakan dalam penelitian ini adalah kuantitatif. Penelitian kuantitatif adalah suatu penelitian yang didasari oleh falsafah positivisme yaitu ilmu yang valid, ilmu yang di bangun dari empiris, teramati, terukur, menggunakan logika matematika dan membuat generalisasi atas rata-rata. (Hidayat dan Sedarmayanti: 2002: 35). Penelitian ini menggunakan penelitian kuantitatif, karena penelitian ini bersifat menganalisa laporan keuangan pada Perusahaan Plastik dan Kemasan yang terdaftar di Bursa Efek Indonesia dan menafsirkan hasilnya dalam bentuk angka-angka, yang diperoleh dari situs www.icmd.co.id dan www.idx.co.id. Populasi merupakan keseluruhan unsurunsur yang memiliki ciri dan karakteristik yang sama. Data yang digunakan dalam penelitian ini adalah data sekunder dengan merujuk pada laporan keuangan Perusahaan Plastik dan Kemasan tahun 2012-2016 yaitu 13 perusahaan. Sampel 
merupakan bagian dari jumlah dan karakteristik yang dimiliki populasi tersebut (Sugiyono, 2009). Teknik yang digunakan dalam pengambilan sampel menggunakan metode purposive sampling, yaitu metode penentuan sampel dengan pertimbangan tertentu (Sugiyono, 2009), dengan menggunakan kriteria sebagai berikut :

a. Perusahaan Plastik dan Kemasan yang terdaftar dalam Bursa Efek Indonesia selama periode penelitian (2012 - 2016).

b. Perusahaan tersebut menerbitkan laporan keuangan tahunan secara berturut-turut selama periode penelitian $(2012$ - 2016) dan dapat diakses oleh publik.

Teknik pengumpulan data dilakukan dengan metode dokumentasi, yaitu dengan mencatat dan mengumpulkan data yang tercantum pada Bursa Efek Indonesia yang diakses melalui situs resmi www.idx.co.id yang berupa laporan keuangan perusahaan Plastik dan kemasan. Data yang digunakan dalam penelitian ini yaitu laporan keuangan tahunan dari setiap perusahaan yang merupakan sampel penelitian tahun 2012-2016 dan harga saham. Defenisi operasional variabel penelitian adalah :

Tabel 1

Defenisi Operasional Variabel

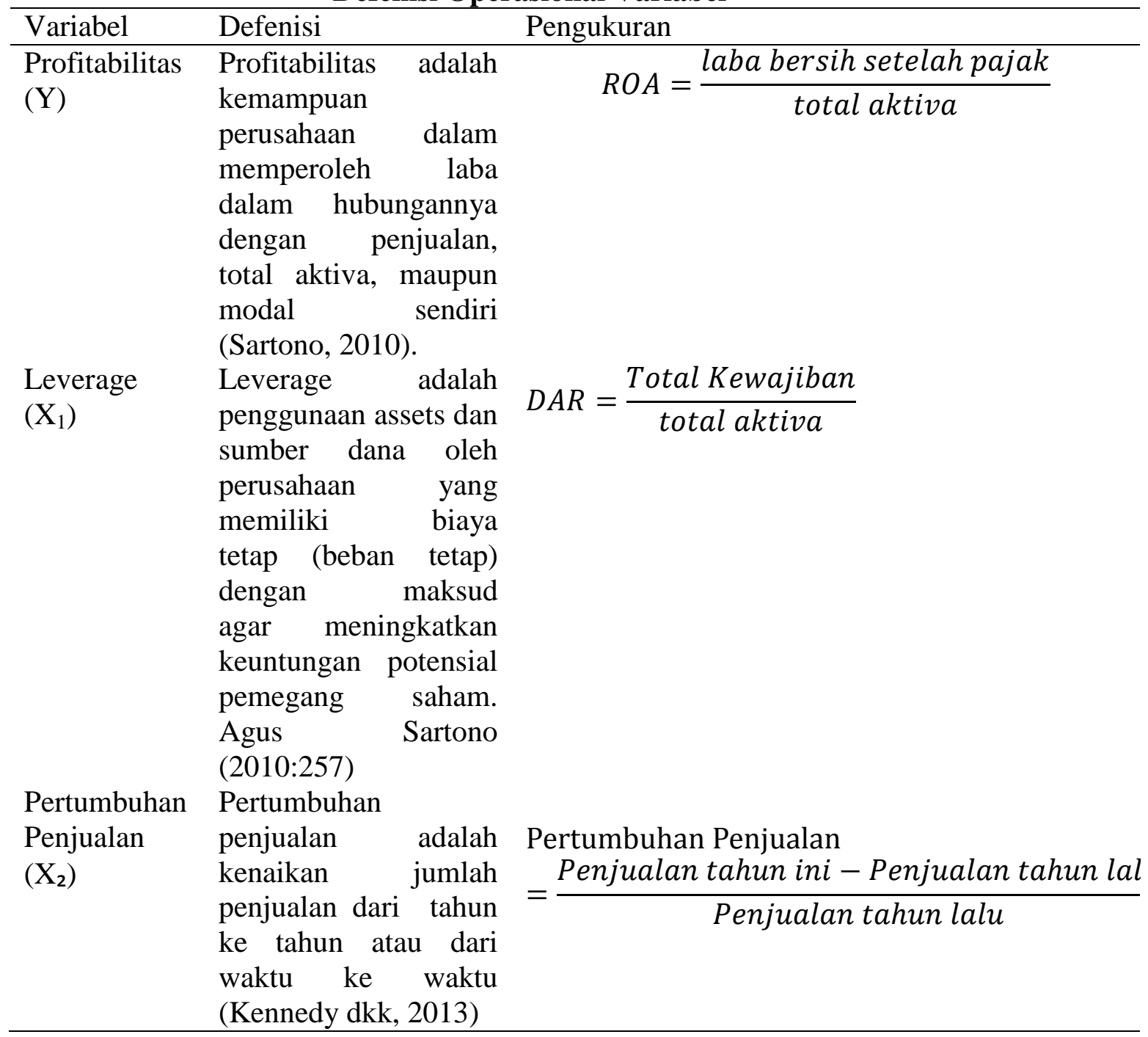




\begin{tabular}{|c|c|c|}
\hline $\begin{array}{l}\text { Ukuran } \\
\text { Perusahaan } \\
\left(\mathrm{X}_{3}\right)\end{array}$ & $\begin{array}{lr}\text { Ukuran perusahaan } \\
\text { adalah rata-rata } \\
\text { penjualan bersih untuk } \\
\text { tahun } \\
\text { bersangkutan } & \text { sampai } \\
\text { beberapa } & \text { tahun. } \\
\text { Dalam hal ini } \\
\text { penjualan lebih besar } \\
\text { dari pada biaya } \\
\text { variabel dan biaya } \\
\text { tetap, maka akan } \\
\text { diperoleh jumlah } \\
\text { pendapatan sebelum } \\
\text { pajak (Brigham dan } \\
\text { Houston, 2001). }\end{array}$ & Size it $=\log$ Total Asset it \\
\hline
\end{tabular}

Digunakan untuk memberikan gambaran mengenai faktor - faktor yang mempengaruhi variable, baik secara numerik misalnya menghitung rata - rata, standar deviasi atau secara grafis dalam bentuk tabel atau grafik. Untuk mendapatkan gambaran umum tentang data yang diperoleh sebagai acuan untuk melihat karakteristik data yang diperoleh.

Stasioner merupakan suatu kondisi data time series yang jika rata - rata varian dan covarian dari perubahan tersebut seluruhnya tidak dipengaruhi oleh waktu. Metode yang digunakan adalah metode Augmented Dickey Fuller (ADF) dan Philps Perron (PP). Uji normalitas adalah bertujuan untuk menguji apakah dalam model regresi, variable pengganggu atau residual mempunyai distribusi normal atau tidak (Ghozali, 2006:110) dalam (Sansoethan and Suryono, 2016) . Uji normalitas digunakan untuk menguji apakah sebuah model regresi, variabel dependen, variabel independen, dan keduanya mempunyai distribusi normal atau tidak. Model regresi yang baik adalah data distribusi normal dan merata. Uji normalitas bertujuan untuk menguji apakah model regresi, variabel pengganggu atau residual mempunyai distribusi normal atau tidak. Data distribusi normal dapat dilihat jika nilai probability Jarque-Bera> tingkat alpha 5\% maka data terdistribusi secara normal, sebaliknya jika nilai probability Jarque-Bera $<$ tingkat alpha 5\% maka data tidak terdistribusi secara normal.

1. Uji multikolinieritas yaitu hubungan sesama variabel bebas. Multikolinearitas adalah keadaan dimana variabel - variabel independen dalam pesamaan regresi mempunyai korelasi (hubungan) yang erat satu sama lain. Salah satu tujuan dilakukannya pengujian ini adalah untuk mengetahui apakah sesama variabel independen terjadi korelasi atau hubungan antara satu variabel dengan variabel lain. Uji Multikolinearitas dilakukan denga model regresi linier klasik apabila memiliki independen lebih dari satu. Syarat tidak terjadi Multikolinearitas adalah jika nilai korelasi antara variabel independen $<0,8$. Jika nilai korelasi $<0,8$. Jika korelasi $>0,8$ maka terjdi Multikolinearitas.

2. Uji heteroskedastisitas bertujuan untuk menguji apakah dalam model regresi terjadi tidak kesamaan variable ldari residual satu pengamatan ke pengamatan lain. Jika variance dari residual satu pengamatan ke 
pengamatan lain tetap, maka disebut homoskodestisitas atau tidak terjadi hetekedastisitas (Ghozali, 2006:69) dalam (Ichwan and Widyawati, 2015). Uji heteroskedastisitas dilakukan dengan uji Glejser untuk mengetahui apakah data tersebar secara merata atau tudak, yang diinginkan tidak terjadi heteroskedastisitas atau sebaran data merata dan tidak membentuk suatu pola tertentu. Caranya dengan melihat white heteroskedastisity test, dimana nilai probability $O b s * R$-Squared $>0,05$ (alpha). Oleh karena itu nilai probability Obs*R-Squared > 0,05 , maka tidak terjadi heteroskedastisitas.

3. Uji autokerelasi digunakan untuk melihat ada tidaknya autkorelasi, autokorelasi adalah korelasi yang terjadi diantara anggota - anggota dari serangkaian pengamatan yang tersusun dalam data time series. Apabila terjadi autokorelasi di dalam suatu model, artinya varian sampel tidak menggambarkan varian populasinya. Dalam keadaan seperti ini model regresi yang dihasilkan tidak dapat digunakan untuk menaksir nilai variabel dependen pada variabel independen tertentu. Model penelitian yang baik adalah tidak terjadi autokorelasi. Uji Deteksi adanya autokorelasi bisa dilihat pada tabel Durbin-Waston (Santoso, 2001:218) dalam (Sansoethan and Suryono, 2016), secara umum bisa diambil patokan sebagai berikut: (a) Angka D-W di bawah -2 berarti ada autokorelasi positif, (b) Angka D-W diantara -2 sampai +2 , berarti tidak ada autokorelasi, dan (c) Angka D-W di atas -2 bararti ada autokorelasi negatif.

4. Analisis regresi linier berganda adalah hubungan secara linear antara dua atau lebih variabel independen $(\mathrm{X} 1, \mathrm{X} 2, \ldots \ldots . \mathrm{Xn})$ dengan variabel $\mathrm{Y}$. Analisis ini untuk mengetahui arah hubungan antar variabel independen dengan variabel dependen apakah masing - masing variabel dependen berhubungan positif atau negatif dan untuk memprediksi nilai variabel dependen apabila nilai variabel independen mengalami kenaikan atau penurunan. Data yang digunakan biasanya berskala interval atau rasio. Penelitian ini menggunakan Analisis Regresi linear berganda dengan model Regresi :

$\mathrm{Y}=\mathrm{a}+\mathrm{b}_{1} \mathrm{x}_{1}+\mathrm{b}_{2} \mathrm{x}_{2}+\mathrm{b}_{3} \mathrm{x}_{3}+\mathrm{e}$

Dimana :

$\mathrm{Y}=$ Profitabilitas

$\mathrm{a}=$ Konstanta

$\mathrm{b}_{1}=$ Koefisien Leverage

$\mathrm{x}_{1}=$ Leverage

$\mathrm{b}_{2}=$ Koefisien Pertumbuhan Penjualan

$\mathrm{x}_{2}=$ Pertumbuhan Penjualan

$\mathrm{b}_{3}=$ Koefisien Ukuran Perusahaan

$\mathrm{x}_{3}=$ Ukuran Perusahaan

e $=$ Standar Error

5. Uji $\mathrm{F}$ digunakan untuk menguji pengaruh variabel independen yaitu Leverage, Pertumbuhan Penjualan dan Ukuran Peruahaan secara bersama - sama terhadap variabel dependen yaitu Profitabilitas dari suatu persamaan regresi yang didasarkan pada nilai probabilitas $\mathrm{a}=$ 0,05 dengan kriteria pengujian sebagai berikut : 
Jika probabilitas $>0,05 \mathrm{H}_{\mathrm{a}}$ ditolak, $\mathrm{H}_{\mathrm{o}}$ diterima

Jika probabilitas $<0,05 \mathrm{H}_{\mathrm{a}}$ diterima, $\mathrm{H}_{\mathrm{o}}$ ditolak

6. Uji t digunakan untuk menguji pengaruh variabel independen secara persial terhadap variabel dependen yaitu pengaruh dari variabel independen (Leverage, Pertumbuhan Penjualan dan Ukuran Perusahaan) terhadap variabel dependen yaitu (Profitabilitas) yang didasarkan pada nilai probabilitas $\mathrm{a}=0,05$ dengan kriteria pengujian sebagai berikut :

Jika probabilitas $>0,05 \mathrm{H}_{\mathrm{a}}$ ditolak, $\mathrm{H}_{\mathrm{o}}$ diterima

Jika probabilitas $<0,05 \mathrm{H}_{\mathrm{a}}$ diterima, $\mathrm{H}_{\mathrm{o}}$ ditolak

$\mathrm{t}_{\text {hitung }}<\mathrm{ttabel}$ maka $\mathrm{H}_{\mathrm{a}}$ ditolak dan $\mathrm{H}_{\mathrm{o}}$ diterima

$t_{\text {hitung }}>$ ttabel maka $\mathrm{H}_{\mathrm{a}}$ diterima dan $\mathrm{H}_{\mathrm{o}}$ ditolak

Suharyadi dan Purwanto (2004:514) dalam (Ichwan and Widyawati, 2015) menyatakan bahwa koefisien determinasi merupakan ukuran untuk mengetahui kesesuaian atau ketepatan hubungan antara variabel independen dengan variabel dependen dalam persamaan suatu regresi. Koefisien determinasi digunakan untuk mengetahui hubungan antara Leverage, Pertumbuhan Penjualan dan Ukuran Perusahaan terhadap Profitabilitas. Koefisien determinasi berkisar dari 0 sampai dengan $1(0 \leq \mathrm{R} 2 \leq 1)$. Hal ini berarti bila $\mathrm{R} 2=0$ menunjukkan tidak adanya pengaruh antara variabel dependen, apabila R2 semakin besar terhadap variabel dependen dan bila R2 semakin kecil mendekati 0 maka dapat dikatakan semakin kecilnya pengaruh variabel independen terhadap variabel dependen.

\section{HASIL PENELITIAN DAN PEMBAHASAN}

Penelitian ini dibantu dengan eviews 9.0. Uji analisis deskriptif berguna untuk melihat kondisi nilai data yang diteliti pada setiap variabel. Dalam analisis deskriptif dapat diketahui nilai rata-rata, tertinggi, terendah, dan simpangan baku yang terbentuk. Bentuk simpangan baku apakah melebih kecil atau lebih besar dari nilai rata-rata yang diperoleh oleh perusahaan. Jika rata-rata lebih tinggi dari standar baku maka data secara statistik bernilai positif, begitu juga sebaliknya.

\section{Tabel 2}

Hasil Uji Analisis Deskriptif

Date: 02/04/18 Time: 12:50

Sample: 155

\begin{tabular}{lrrrr}
\hline \hline & PROFITABILI... & LEVERAGE & PERTM_PE... UKUR_PER... \\
\hline \hline Mean & 1.236445 & 0.516297 & 13.91756 & 5.822347 \\
Median & 1.059553 & 0.506210 & 4.450348 & 5.502752 \\
Maximum & 15.77050 & 1.004460 & 294.3011 & 8.029452 \\
Minimum & -19.15369 & 0.149538 & -107.0757 & 4.602939 \\
Std. Dev. & 6.876313 & 0.209330 & 62.03381 & 0.739908 \\
Skewness & -0.413211 & 0.485661 & 2.943038 & 1.100151 \\
Kurtosis & 4.484582 & 2.930500 & 13.64121 & 4.337517 \\
\hline
\end{tabular}

Nilai rata-rata variabel profitabilitas adalah sebesar 1,23\% dengan standar deviasi sebesar 6,87\% serta nilai tertinggi yang terbentuk adalah sebesar 15,77\% yaitu perusahaan Champion Pasific Indonesia Tbk pada tahun 2016 dan nilai terendah yang terbentuk adalah sebesar $-19,15 \%$ yaitu perusahaan Alam Karya Unggul Tbk pada tahun 2012. Nilai rata-rata profitabilitas lebih kecil dari standar 
bakunya maka data secara statistik bernilai negatif akan tetapi tidak akan mempengaruhi kualitas data yang diteliti.

Nilai rata-rata variabel leverage adalah sebesar 0,51 dengan standar deviasi sebesar 0,20 serta nilai tertinggi sebesar 1,00 yaitu pada perusahaan Sekawan Intipratama Tbk pada tahun 2016 dan nilai terendah sebesar 0,14 yaitu pada perusahaan Champion Pasific Indonesia Tbk pada tahun 2016. Nilai rata-rata leverage lebih besar dari standar deviasinya maka secara statistik data telah bernilai positif dan baik untuk pengujian selanjutnya.

Nilai rata-rata variabel pertumbuhan penjualan sebesar $13,91 \%$ dengan standar deviasinya sebesar $62,03 \%$ serta nilai tertinggi sebesar $294,30 \%$ pada perusahaan Alam Karya Unggul Tbk dan nilai terendah sebesar -107,07\% pada perusahaan Sekawan Inti Pratama pada tahun 2016. Nilai rata-rata pertumbuhan penjualan lebih kecil dari standar deviasinya maka secara statistik data bernilai negatif akan tetapi tidak mempengaruhi kualitas data yang akan diteliti.

Nilai rata-rata variabel ukuran perusahaan sebesar 5,82 dengan standar deviasi sebesar 0,73 serta nilai tertinggi sebesar 8,02 yaitu pada perusahaan Alam Karya Unggul Tbk dan nilai terendah sebesar 4,60 pada perusahaan Siwani Makmur Tbk. Nilai rata-rata ukuran perusahaan lebih besar dari standar deviasinya maka secara statistik data bernilai positif.

Uji stasioner dipergunakan untuk data yang semi runtut waktu atau yang lebih dikenal dimana perubahan data tidak dipengaruhi oleh runtut waktu. Hasil uji terpenuhi apabilai nilai probabilitas pada Augmented Dickey Fuller (ADF) dan Philps Perron (PP) lebih kecil dari alpha 0,05.

Tabel 3

Hasil Uji Stasioner

\begin{tabular}{|c|c|c|}
\hline Uji Stasioner & Probabilitas & Hasil \\
\hline ADF & 0,0000 & Stasioner \\
\hline PP & 0,0000 & Stasioner \\
\hline
\end{tabular}

Nilai probabilitas ADF sebesar $0,000<0,05$ maka uji stasioner dengan metode ADF telah terpenuhi. Hasil uji stasioner dengan metode Philps Perron (PP) adalah dimana nilai probabilitas yang dibentuk sebesar $0,000<0,05$ maka uji stasioner telah terpenuhi atau data dapat dikatakan telash stasioner. Pada penelitian ini dimana uji stasioner dengan menggunakan kedua metode yaitu ADF dan PP telah terpenuhi. Artinya penyebaran data tidak lagi dipengaruhi dengan perubahan waktu yang diteliti.

Tabel 4

Hasil Uji Normalitas Data

\begin{tabular}{ccc|}
\hline Uji Normalitas & Probabilitas & Hasil \\
\hline Residuals & 0,086981 & Terdistribusi Normal \\
\hline
\end{tabular}

Uji normalitas data gunanya untuk melihat sebaran data secara normal atau distribusi normal. Uji yang digunakan adalah Jarque Berra dimana nilai probabilitas harus lebih besar dari alpha 0,05 maka uji normalitas telah tepenuhi atau dapat dikatakan bahwa penyebaran data yang terbentuk telah berdistribusi dengan normal. Jika menggunakan regresi dan uji t parsial maka data yang akan diuji kenormalannya adalah pada nilai residual yang dibentuk. Nilai probabilitas Jarque Berra adalah sebesar 0,086 > 0,05 yang artinya uji normalitas terpenuhi. Maka data dapat dikatakan telah terdistribusi normal sehingga bisa untuk alat uji statistik selanjutnya. 
Tabel 5

Hasil Uji Multikolinearitas

\begin{tabular}{|l|c|c|c|}
\hline \multicolumn{1}{|c|}{ Variabel } & Correlation & Cut Off & Hasil \\
\hline $\begin{array}{l}\text { Leverage-Pertumbuhan } \\
\text { Penjualan }\end{array}$ & 0,0350 & 0,8 & $\begin{array}{c}\text { Tidak } \\
\text { Multikolinearitas }\end{array}$ \\
\hline Leverage-Ukuran Perusahaan & 0,2120 & 0,8 & $\begin{array}{c}\text { Tidak } \\
\text { Multikolinearitas }\end{array}$ \\
\hline $\begin{array}{l}\text { Pertumbuhan Penjualan- } \\
\text { Ukuran Perusahaan }\end{array}$ & 0,3148 & 0,8 & $\begin{array}{c}\text { Tidak } \\
\text { Multikolinearitas }\end{array}$ \\
\hline
\end{tabular}

Uji multikolinearitas digunakan untuk mengukur korelasi data antar variabel independen. Alat uji yang digunakan adalah correlation matrik dimana nilai korelasi yang terbentuk harus kecil dari 0,8 .

Nilai korelasi leverage-pertumbuhan penjualan adalah sebesar $0,03<0,8$ maka tidak terjadi multikolinearitas. Nilai korelasi leverage-ukuran perusahaan adalah sebesar 0,21 < 0,8 maka tidak terjadi multikolinearitas. Nilai korelasi pertumbuhan penjualan-ukuran perusahaan adalah sebesar $0,31<0,8$ maka tidak terjadi multikolinearitas. Dari analisa tersebut dapat dijelaskan kembali bahwa seluruh data dalam variabel ini telah lulus asumsi multikolinearitas atau dengan kalimat lain tidak terdapat adanya bentuk multikolinearitas.

\section{Tabel 6}

Hasil Uji Heteroskedastisitas

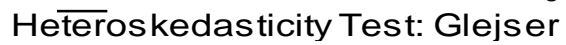

\begin{tabular}{llll}
\hline \hline F-statistic & 1.393709 & Prob. F(3,51) & 0.2553 \\
Obs*R-squared & 4.167404 & Prob. Chi-Square(3) & 0.2439 \\
Scaled explained SS & 5.007902 & Prob. Chi-Square(3) & 0.1712 \\
\hline \hline
\end{tabular}

Uji heteroskedastisitas difungsikan untuk melihat keberagaman varian pada data yang diteliti. Alat uji yang digunakan adalah uji Glejser dimana nilai probabilitasnya harus lebih besar dari alpha 0,05 maka dapat dikatakan tidak ada heteroskedastisitas. Nilai probabilitas Obs*R-squared adalah sebesar 0,2439 > 0,05 maka dapat dikatakan tidak ada heteroskedastisitas. Dengan kata lain data dalam penelitian ini tidak terjadi gejala heteroskedastisitas atau uji heteroskedastisitas telah terpenuhi.

\section{Tabel 7}

Hasil Uji Autokorelasi

\begin{tabular}{|c|c|c|}
\hline Uji Autokorelasi & Nilai & Hasil \\
\hline Durbin Watson & 1,5786 & Tidak Autokorelasi \\
\hline
\end{tabular}

Uji autokorelasi digunakan untuk melihat korelasi data antara variabel independen dengan variabel dependennya apabila data yang digunakan berbentuk time series. Uji autokorelasi pada penelitian ini menggunakan uji Durbin Watson dimana nilai DW berada diantara -2 sampai +2 maka uji autokorelasi telah terpenuhi. Nilai DW sebesar 1,57 berada diantara -2 sampai +2 maka uji autokorelasi telah terpenuhi. Dengan kata lain tidak terdapat autokorelasi pada bentuk penelitian ini sehingga data dapat digunakan pada uji statistik selanjutnya.

Uji regresi linear berganda dipergunakan untuk melihat perubahan dari nilai variabel dependen jika dihadapkan kepada variabel independen. Rumus dalam regresi linear berganda adalah :

$\mathrm{Y}=\mathrm{a}+\mathrm{b}_{1} \mathrm{X}_{1}+\mathrm{b}_{2} \mathrm{X}_{2}+\mathrm{b}_{3} \mathrm{X}_{3}+\mathrm{e}$ 
Persamaan yang dapat dibentuk dari hasil uji statistik adalah :

$$
\mathrm{Y}=15,833-15,572 \mathrm{X}_{1}+0,001 \mathrm{X}_{2}-1,129 \mathrm{X}_{3}+\mathrm{e}
$$

\section{Tabel 8}

\section{Hasil Uji Regresi Linear Berganda}

\begin{tabular}{|c|c|c|c|c|}
\hline Variable & Coefficient & Std. Error & t-Statistic & Prob. \\
\hline 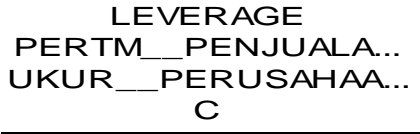 & $\begin{array}{r}-15.57272 \\
0.001380 \\
-1.129487 \\
15.83365\end{array}$ & $\begin{array}{l}4.043851 \\
0.014050 \\
1.204626 \\
6.871643\end{array}$ & $\begin{array}{r}-3.850963 \\
0.098244 \\
-0.937625 \\
2.304201\end{array}$ & $\begin{array}{l}0.0003 \\
0.9221 \\
0.3529 \\
0.0253\end{array}$ \\
\hline $\begin{array}{l}\text { R-squared } \\
\text { Adjusted R-squared } \\
\text { S.E. of regression } \\
\text { Sum squared resid } \\
\text { Log likelihood } \\
\text { F-statistic } \\
\text { Prob(F-statistic) }\end{array}$ & $\begin{array}{r}0.262733 \\
0.219364 \\
6.075470 \\
1882.478 \\
-175.1994 \\
6.058126 \\
0.001311\end{array}$ & \multicolumn{2}{|c|}{$\begin{array}{l}\text { Mean dependent var } \\
\text { S.D. dependent var } \\
\text { Akaike info criterion } \\
\text { Schwarz criterion } \\
\text { Hannan-Quinn criter. } \\
\text { Durbin-Watson stat }\end{array}$} & $\begin{array}{l}1.236445 \\
6.876313 \\
6.516343 \\
6.662331 \\
6.572797 \\
1.578628\end{array}$ \\
\hline
\end{tabular}

Nilai konstanta yang terbentuk adalah 15,833 dengan tanda positif dimana apabila data independen (leverage, pertumbuhan penjualan, dan ukuran perusahaan) bernilai tetap (konstan) atau nol maka profitabilitas telah meningkat sebesar $15,83 \%$. Nilai koefisien regresi leverage adalah sebesar -15,572 dengan tanda negatif. Hubungan yang terbentuk bersifat berlawanan arah, yang artinya bahwa apabila leverage meningkat maka nilai profitabilitas akan menurun. Nilai koefisien regresi pertumbuhan penjualan adalah 0,001 dengan tanda positif. Hubungan yang terbentuk bersifat searah, yang artinya bahwa apabila pertumbuhan penjualan meningkat maka profitabilitas juga akan meningkat. Nilai koefisien regresi ukuran perusahaan adalah sebesar -1,129 dengan tanda negatif. Hubungan yang terbentuk bersifat berlawanan arah, artinya bahwa apabila ukuran perusahaan meningkat maka profitabilitas menurun.

Uji koefisien determinan merupakan uji yang menggambarkan seberapa kuat variabel independen dalam menjelaskan korelasinya dengan variabel dependen. Berdasarkan tabel 4.8 dimana nilai adjusted $\mathrm{R}$ square yang terbentuk adalah sebesar 0,2194. Artinya kemampuan variabel leverage, pertumbuhan penjualan, dan ukuran perusahaan secara keseluruhan mempengaruhi profitabilitas adalah sebesar $21,94 \%$ sedangkan sisanya sebesar 78,06\% dipengaruhi oleh variabel lain yang bukan dari variabel yang diteliti dalam penelitian ini seperti rasio utang.

Uji F simultan difungsikan untuk melihat ada atau tidaknya pengaruh antara variabel independen terhadap variabel dependen secara simultan (bersamaan). Uji F simultan dibentuk dengan kriteria apabila nilai probabilitas < alpha 0,05 maka variabel independen berpengaruh secara bersamaan terhadap variabel dependennya.

Berdasarkan tabel 4.9 dijelaskan bahwa nilai probabilitas sebesar $0,001<$ 0,05 maka $\mathrm{H}_{\mathrm{a}}$ diterima dan $\mathrm{H}_{0}$ ditolak. Hal ini dapat disimpulkan bahwa variabel independen yang terdiri dari leverage, pertumbuhan penjualan, dan ukuran perusahaan berpengaruh secara bersamaan (simultan) terhadap variabel dependen yang terdiri dari profitablitas. 
Uji $\mathrm{t}$ parsial diperuntukkan untuk dapat melihat pengaruh variabel independen terhadap variabel dependen secara parsial atau satu per satu. Uji $t$ parsial terpenuhi apabila nilai probabilitas < alpha 0,05 maka dapat dikatakan terdapat pengaruh antara variabel independen(leverage, pertumbuhan penjualan, dan ukuran perusahaan) terhadap variabel dependennya (profitabilitas). Hasil uji t parsial dalam penelitian ini yang berdasarkan kepada tabel 4.9 adalah :

a. Nilai probabilitas untuk variabel leverage adalah sebesar 0,0003 $<0,05$ dan nilai $t_{\text {hitung }}>$ ttabel $(3,850>1,673)$ maka $\mathrm{H}_{\mathrm{a}}$ diterima dan $\mathrm{H}_{\mathrm{o}}$ ditolak. Artinya variabel leverage berpengaruh negatif dan signifikan terhadap profitabilitas perusahaan.

b. Nilai probabilitas untuk pertumbuhan penjualan adalah sebesar 0,9221 > 0,05 dan nilai $t_{\text {hitung }}<$ ttabel $(0,0982<1,673)$ maka $\mathrm{H}_{\mathrm{a}}$ ditolak dan $\mathrm{H}_{\mathrm{o}}$ diterima. Artinya variabel pertumbuhan penjualan tidak berpengaruh signifikan terhadap profitabilitas perusahaan.

c. Nilai probabilitas untuk variabel ukuran perusahaan adalah sebesar 0,3529 $>0,05$ dan nilai $t_{\text {hitung }}<$ thabel $(0,0982<1,673)$ maka $\mathrm{H}_{\mathrm{a}}$ ditolak dan $\mathrm{H}_{\mathrm{o}}$ diterima. Artinya variabel ukuran perusahaan tidak berpengaruh signifikan terhadap profitabilitas perusahaan.

\section{Pembahasan}

\section{Pengaruh Leverage Terhadap Profitabilitas Perusahaan}

Hipotesis pertama dalam penelitian ini adalah dimana terdapat pengaruh yang signifikan antara leverage terhadap profitabilitas perusahaan. Berdasarkan analisa regresi linear berganda dimana jika leverage meningkat maka profitabilitas akan menurun. Hasil ini sesuai dengan uji t parsial dimana nilai probabilitas sebesar $0,0003<0,05$ maka kesimpulan yang terbentuk adalah leverage berpengaruh negatif dan signifikan terhadap profitabilitas dimana setiap peningkatan leverage maka profibalitas akan mengalami penurunan.

Hubungan yang terbentuk adalah bersifat negatif karena leverage merupakan rasio yang menggambarkan penggunaan utang dalam membiayai investasi perusahaan. Investasi yang dimaksud adalah penggunaan aktiva perusahaan. Nilai leverage menjelaskan proporsi tingkat dana perusahaan dalam membayar beban tetap. Apabila rasio leverage meningkat maka penggunaan aktiva perusahaan menjadi tidak efektif karena digunakan dalam menutupi beban tetap (kewajiban) perusahaan sehingga akan menurunkan laba perusahaan (profitabilitas).

Perkembangan leverage adalah sebesar 0,51 dimana hal ini menjelaskan bahwa utang perusahaan sebagian besar didanai melalui aktiva perusahaan sehingga akan mengurangi laba yang diperoleh (profitabilitas). Hal inilah yang menyebabkan bahwa leverage memiliki hubungan yang negatif dengan profitabilitas perusahaan.

Hasil penelitian ini mendukung hasil penelitian sebelumnya yang dilakukan oleh Bajra (2013) yang menyimpulkan bahwa adanya pengaruh negatif antara leverage terhadap profitabilitas perusahaan. Penelitian yang juga dilakukan oleh Nugroho (2011) juga menyimpulkan hal yang sama dimana leverage berpengaruh negatif terhadap profitabilitas perusahaan.

\section{Pengaruh Pertumbuhan Penjualan Terhadap Profitabilitas Perusahaan}

Hipotesa kedua dalam penelitian ini adalah dimana terdapat pengaruh yang signifikan antara pertumbuhan penjualan terhadap profitabilitas. Berdasarkan uji 
regresi linear berganda dapat dijelaskan bahwa jika pertumbuhan penjualan meningkat maka profitabilitas juga akan meningkat. Namun hal ini tidak sejalan dengan uji t parsial yang dilakukan dimana nilai probabilitas uji t parsial untuk pertumbuhan penjualan adalah sebesar 0,9221 > 0,05 yang dapat disimpulkan bahwa pertumbuhan penjualan tidak berpengaruh terhadap profitabilitas.

Pertumbuhan penjualan merupakan aspek dasar dalam mencapai tujuan perusahaan yaitu menghasilkan laba. Hubungan yang terbentuk adalah positif meskipun tidak memiliki pengaruh. Secara teori dimana indikator dasar dalam membentuk laba perusahaan terletak dari seberapa besar penjualan yang dihasilkan oleh perusahaan selama satu periode akuntansi dan sekecil apa biaya yang dihasilkan oleh perusahaan dalam menopang penjualan. Jika penjualan meningkat dengan biaya tetap atau menurun maka laba juga juga akan meningkat. Jika penjualan menurun dengan biaya yang meningkat maka akan memperkecil laba atau akan menciptakan kerugian.

Tidak adanya pengaruh pertumbuhan penjualan terjadi karena rata-rata pertumbuhannya hanya mencapai $13,91 \%$, hal ini merupakan sesuatu yang biasa dan relatif kecil sehingga tidak mempengaruhi laba perusahaan. Dengan pertumbuhan yang relatif kecil dengan rasio profitabilitas yang tinggi maka pertumbuhan laba tidak mampu mempengaruhi profitabilitas karena tingkat profitabilitas akan lebih didominasi oleh utang. Maka pertumbuhan penjualan tidak berpengaruh terhadap profitabilitas.

Hasil penelitian ini didukung oleh penelitian sebelumnya yang dilakukan oleh Nugroho (2011) yang menyimpulkan bahwa tidak ada pengaruh (tidak signifikan) antara pertumbuhan penjualan terhadap profitabilitas perusahaan. Penelitian yang juga dilakukan oleh Putra (2015) yang menyimpulkan bahwa tidak ada pengaruh (tidak signifikan) antara pertumbuhan penjualan terhadap profitabilitas perusahaan.

\section{Pengaruh Ukuran Perusahaan Terhadap Profitabilitas Perusahaan}

Hipotesis ketiga dalam penelitian ini adalah dimana terdapat pengaruh antara ukuran perusahaan terhadap profitabilitas. Hasil uji regresi linear berganda menjelaskan bahwa jika ukuran perusahaan meningkat maka profitabilitas akan menurun. Namun hal ini tidak sejalan dengan uji $t$ parsial dimana nilai probabilitas uji t parsial adalah sebesar 0,3529>0,05 maka dapat disimpulkan bahwa ukuran perusahaan tidak berpengaruh terhadap profitabilitas.

Hubungan yang terbentuk bersifat negatif dimana semakin tinggi ukuran perusahaan maka semakin turun profitabilitasnya. Secara teori apabila ukuran perusahaan yang diproksikan pada nilai aktivanya jika meningkat dengan batas yang wajar maka tidak akan mempengaruhi laba perusahaan karena biaya dalam peningkatan nilai aktiva dapat ditanggulangi melalui laba. Namun jika nilai aktiva yang diproksikan meningkat dengan batas yang tidak wajar maka akan mempengaruhi laba dimana laba akan mengalami penurunan, karena bertambahnya biaya yang harus dikeluarkan perusahaan dalam merawat aktiva baru.

Tidak adanya pengaruh antara ukuran perusahaan terhadap profitabilitas terjadi karena rata-rata perkembangan ukuran perusahaan hanya 5,82 saja dimana hal ini tergolong rendah. Ukuran perusahaan menggambarkan posisi harta perusahaan. Perubahan dari harta perusahaan relatif stabil sehingga tidak 
mengganggu profitabilitas perusahaan sehingga ukuran perusahaan tidak berpengaruh terhadap tingkat profitabilitas perusahaan.

Hasil penelitian ini mendukung hasil penelitian sebelumnya yang dilakukan oleh Bajra (2013) yang menyimpulkan bahwa tidak ada pengaruh (tidak signifikan) antara ukuran perusahaan terhadap profitabilitas perusahaan. Penelitian yang juga dilakukan oleh Putra (2015) menyimpulkan bahwa tidak adanya pengaruh (tidak signifikan) terhadap profitabilitas perusahaan.

\section{SIMPULAN}

Setelah dilakukan serangkaian pengujian statistik, maka diperoleh kesimpulan dalam penelitian ini, yaitu :

1. Berdasarkan uji t parsial dimana nilai probabilitas leverage adalah sebesar $0,0003<0,05$ maka dapat disimpulkan bahwa leverage berpengaruh negatif dan signifikan terhadap profitabilitas perusahaan.

2. Berdasarkan uji $\mathrm{t}$ parsial dimana nilai probabilitas pertumbuhan penjualan adalah sebesar 0,9221 > 0,05 maka dapat disimpulkan bahwa pertumbuhan penjualan tidak berpengaruh terhadap profitabilitas perusahaan.

3. Berdasarkan uji t parsial dimana nilai probabilitas ukuran perusahaan adalah sebesar 0,3529>0,05 maka dapat disimpulkan bahwa ukuran perusahaan tidak berpengaruh terhadap profitabilitas perusahaan.

\section{UCAPAN TERIMA KASIH}

Terima kasih peneliti sampaikan kepada Bapak Febryandhie Ananda S.E, M.Si selaku ketua STIE'KBP” Padang, Ibu Febsri Susanti S.E, MM selaku ketua program studi manajemen, Ibu Aminar Sutra Dewi, S.E M.Si selaku pembimbing skripsi serta Bapak Irdha Yusra S.E, M.Sc selaku pembimbing akademik dan pihak-pihak didalam maupun diluar lingkungan civitas akademika STIE"KBP" Padang yang telah memberikan bantuan dan saran yang membangun terciptanya skripsi ini sehingga menciptakan hasil yang memuaskan.

\section{DAFTAR PUSTAKA}

Afriyeni, A., \& Marlius, D. (2017). Analisis Pengaruh Harga Saham Perdana Terhadap Abnormal Return Yang Diterima Investor Studi Pada Bursa Efek Indonesia. https://doi.org/10.31219/osf.io/8z7hx

Afriyeni, A., \& Marlius, D. (2018). Analisis Pengaruh Informasi Prospektus Perusahaan Terhadap Initial Return Saham Pada Pasar Perdana Di Bursa Efek Indonesia. https://doi.org/10.31219/osf.io/kt6c4

Afriyeni, A., \& Marlius, D. (2019). Analisis Faktor-Faktor Yang Berpengaruh Terhadap Ketepatan Waktu Penyampaian Laporan Keuangan Pada Perusahaan Yang Listing Di Bursa Efek Indonesia. https://doi.org/10.31219/osf.io/rv4qf

Afriyeni, A., \& Marlius, D. (2019). Analisis Tingkat Pengembalian Dan Risiko Investasi (Studi Pada Industri Manufaktur Yang Terdaftar Di Bursa Efek Indonesia). https://doi.org/10.31219/osf.io/cfb92 
Afriyeni, A., \& Fernos, J. (2019). Analisis Pengaruh Faktor Determinan Terhadap Economic Value Added Dan Implikasinya Terhadap Pergerakan Harga Saham Properti Di Bursa Efek Indonesia. https://doi.org/10.31219/osf.io/qf5nm

Ichwan, F. Y. and Widyawati, D. (2015) 'Pengaruh Ukuran Perusahaan, Struktur Aktiva dan Profitabilitas Terhadap Struktur Modal', 4(6), pp. 1-19.

Sansoethan, D. K. and Suryono, B. (2016) 'Faktor-Faktor yang Mempengaruhi Struktur Modal pada Perusahaan Makanan dan Minuman', 5, pp. 1-20.

Sari, D. P., \& Dewi, A. S. (2018). Pengaruh Likuiditas Dan Solvabilitas Terhadap Profitabilitas Pada Perusahaan Makanan Dan Minuman Yang Terdaftar Di Bursa Efek Indonesia Periode 2013-2015. https://doi.org/10.31219/osf.io/n75gr

Sartono, A. (2010) manajemen keuangan teori dan aplikasi. Edisi ke 4. Yogyakarta.

Dewi, A. S. (2017) 'Pengaruh car, bopo, npl, nim, dan ldr terhadap roa pada perusahaan di sektor perbankan yang terdaftar di bei periode 2012-2016', 1(3), pp. 223-236. 